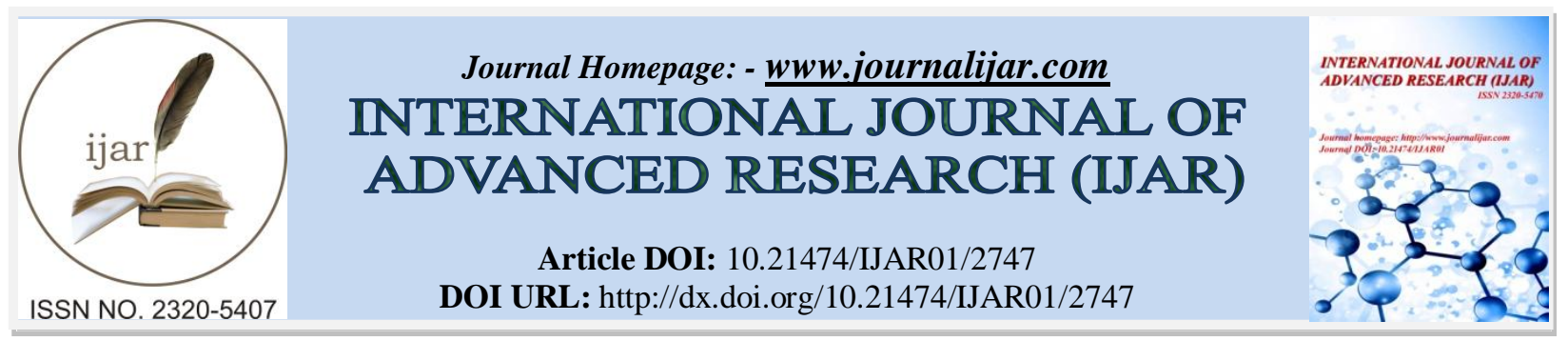

RESEARCH ARTICLE

\title{
CONCENTRATION OF CERAMIDE KINASE (CER) AS ASSAY TO MEASURE CELLULAR LEVELS OF CERAMIDE IN SERUM AND TISSUE BY USING ELIZA TECHNIQUE IN BPH, PC, AND HEALTHY MEN IN IRAQ.
}

Raghdah Abdulmonaam Razoqi, Raid Jasem Mohamed, and usama al nasiri. Department of chemistry and biochemistry Al-Nahrain college of medicine Baghdad. Iraq.

\section{Manuscript Info} .....................

\section{Manuscript History}

Received: 15 November 2016

Final Accepted: 17 December 2016

Published: January 2017

\section{Abstract}

Ceramide is subsequently metabolized by ceramide kinase to generate $\mathrm{C} 1 \mathrm{P}$ and by ceramidase to generate sphingosine, which is further phosphorylated to S1P by sphingosine kinase. Alternatively again, dephosphorylating of the metabolic derivate also occurs using specific phosphatases, such as $\mathrm{C} 1 \mathrm{P}$ phosphatase and S1P phosphatase ceramide can also be produced from sphingosine by ceramide synthasethe dynamic regulation for ceramide generation and metabolism is critical for cellular responses to extracellular stimuli, such as death receptor-mediated (TNF-and Fas), chemotherapeutic agent-mediated using in prostate cancer (zoladex, prostate car, and irradiation-mediated (UV and $\gamma$-irradiation). For tumorigenesis, ceramide acts as a tumor-suppressor lipid, whereas S1P acts as a tumor-promoting lipid in BPH and PC cancer comparing with healthy men.

Copy Right, IJAR, 2016,. All rights reserved.

\section{Introduction:-}

The experimental work was done at The Department of Chemistry and Biochemistry, College of Medicine ALNahrain University, and The Ministry of Science and Technology, during the period from (January to Jun) 2016.Sixty patients from men have malignant prostate cancer and Benign Prostatic Hyperplasia, were chosen to be subjected to this study and divided into two groups. The first group (B) consists of (30) patients of men with (BPH), This group was divided into four sub-groups: two groups were serum tested, and other two groups were tissue tested each group consist of (30) samples which were divided according to doses of drugs (high and low dose). The second group (C) consist of (30) patients of men with malignant prostatic cancer. At the same manner of this groups were divided into four sub-groups: two groups were serum tested, the other two groups were tissue tested. Each group consists of (30) samples which were divided according to chemotherapy doses (high and low doses of chemotherapy). The control group was marked (A) consists of (30) samples of healthy men who were free signs and symptoms of prostate cancer, age ranged from (50- 70) years, were nonsmokers, free from Diabetic mellitus, hypertension, renal function disease, and family history of prostatic cancer. All samples were collected from AlImameen Al-Kademen Medical City, AL-Jawad Oncology Centre, Medical City-Hospital Martyr Ghazi Al-Hariri for Specialized Surgery, AL-Yarmok Hospital, Educational Oncology Hospital,Special Nursing Hospital, and ALSaadon Privet Hospital.

In this study it has been developed through examination to assess the Ceramide kinase as assay to measure concentration of ceramide in Serum and Tissue into three groups (control, BPH, and PC) of patients by using Elisa Kit and this Figure (1) shows standard curve of Ceramide in serum and tissue, and The (Mean \pm SD) of Cer in serum 
and tissue had shown an increase in the patient with BPH and malignant prostatic cancer in comparing to with control group as in Table (1). Membrane sphingolipid, regulators for cell growth, death, senescence, adhesion, migration, angiogenesis, inflammation, and intracellular trafficking, are bioactive metabolites including sphingosine, ceramide, sphingosine-1-phosphate (S1P), and ceramide-1-phosphate (C1P).Apoptosis or Type I programmed cell death, is essential for the maintenance of normal cellular homeostasis and is an important physiological response to many forms of cellular stress. One of the most studied roles of ceramide pertains to its function as a proapoptotic molecule. Ceramide accumulation has been found following treatment of cells with a number of apoptotic agents including ionizing radiation, UV light, TNF-alpha, and chemotherapeutic agents. (Saddoughi et al.,2008).This suggests a role for ceramide in the biological responses of all these agents. Because of its apoptosis-inducing effects in cancer cells, ceramide has been termed the tumor suppressor lipid. Several studies have attempted to define further the specific role of ceramide in the events of cell death and some evidence suggests ceramide functions upstream of the mitochondria in inducing apoptosis. It is owing to the conflicting and variable nature of studies into the role of ceramide in apoptosis, the mechanism by which this lipid regulates apoptosis remains elusive (Spiegel, S, et al, 2002).

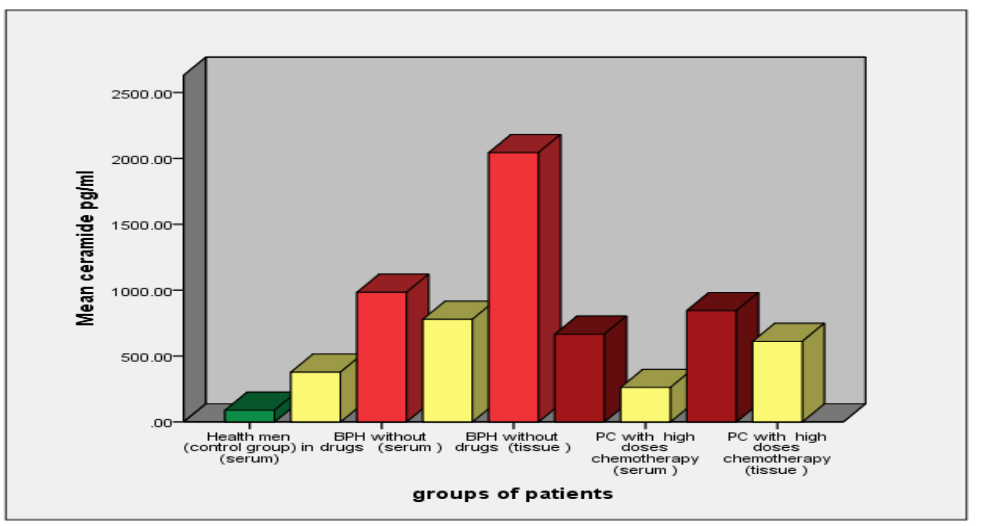

Figure 1:- concentration of Ceramide (pg/ml) in serum and Tissue in BPH, PC, and matched with Healthy Men

Table 1:- Mean \pm SD of Cer levels in men Serum and Tissue with Prostatic Cancer, Benign Prostatic Hyperplasia and Healthy Men

\begin{tabular}{|c|c|c|c|c|}
\hline Groups & $\begin{array}{l}\text { Mean of peak area } \\
\pm \text { SD for serum } \\
\text { groups }\end{array}$ & $\begin{array}{l}\text { P value between } \\
\text { serum groups }\end{array}$ & $\begin{array}{l}\text { Mean of peak area } \\
\pm \text { SD for tissue } \\
\text { groups }\end{array}$ & $\begin{array}{l}\mathbf{P} \text { value between } \\
\text { tissue groups }\end{array}$ \\
\hline Control & $88.73 \pm 43.16$ & & & \multirow[b]{3}{*}{$P<0.001$} \\
\hline BPH without drugs & $377.50 \pm 198.15$ & \multirow[t]{2}{*}{$\mathrm{P}<0.001$} & $778.25 \pm 106.55$ & \\
\hline BPH with drugs & $983.50 \pm 174.67$ & & $2043.62 \pm 38.50$ & \\
\hline $\begin{array}{l}\text { Prostatic cancer low doses } \\
\text { chemotherapy }\end{array}$ & $665.62 \pm 222.17$ & \multirow[t]{2}{*}{$\mathrm{P}<0.001$} & $844.87 \pm 108.79$ & \multirow[t]{2}{*}{$\mathbf{P}<0.001$} \\
\hline $\begin{array}{l}\text { Prostatic cancer high } \\
\text { doses chemotherapy }\end{array}$ & $261.50 \pm 90.37$ & & $610.87 \pm 92.29$ & \\
\hline
\end{tabular}

Determination Concentration of Ceramide kinase (CERK) in Enzyme Linked Immunosorbent Assay (ELIZA) A double -antibody sandwich enzyme-linked immunosorbent one step process assay (ELISA) one stop process was used to measure Ceramide kinase (CERK) in serum and tissue samples.

\section{Standard preparation:-}

The Standard was diluted with Standard diluents in the method of Multiple proportion dilution and the concentrations were followed: $(0,75,150,300,600,1200 \mathrm{pg} / \mathrm{ml})$.

\section{Reagent Preparation:}

$20 \times$ dilution of washing buffer: distilled water, diluted by 1:20, or 1 copy of the $20 \times$ washing buffer plus 19 copies of the distilled water 5 . 


\section{Washing Method:-}

Manually washing method was emptied the plate by inverting it and shaking the content out, and then it was taped on the absorbent papers to dry. At least $0.35 \mathrm{ml}$ washing solution was added into each well, and the plate was soaked for 1 2 minutes. This process was repeated for 5 times.

\section{Operation Steps:-}

Fifty $\mu 1$ of standard were added to standard wells. $40 \mu 1$ of sample diluent were added to sample wells and ten $\mu 1$ of sample were added. $50 \mu \mathrm{l}$ of horseradish peroxidase (HRP) were added into each well, except the blank well, the plate was shacked gently and was incubated $60 \mathrm{~min}$ at $37^{\circ} \mathrm{C}$.

Excess liquid was discarded, the wells then dried, washed with washing solution and dried again .Chromogen solution (A) followed by $50 \mu 1$ of Chromogen solution (B) were added to each well. The plate gently shacked and incubated for 10 minutes at $37^{\circ} \mathrm{C}$ in dark place.Fifty $\mu \mathrm{l}$ of stop solution were added into each well to stop the reaction (the blue changes into yellow immediately).Measurement and standard were the blank wells were set at zero and the optical density (OD) was measured at $450 \mathrm{~nm}$ within $15 \mathrm{~min}$ after adding the stop solution

\section{Standard curve:-}

According to standards concentration and the corresponding OD values, the standard curve linear regression equation was calculated and then the OD values of the sample was applied on the regression equation to calculate the corresponding Figure (2.2) shows the calibration in curve concentration of samples with a rang $>0-<150 \mathrm{ng} / \mathrm{ml}$.

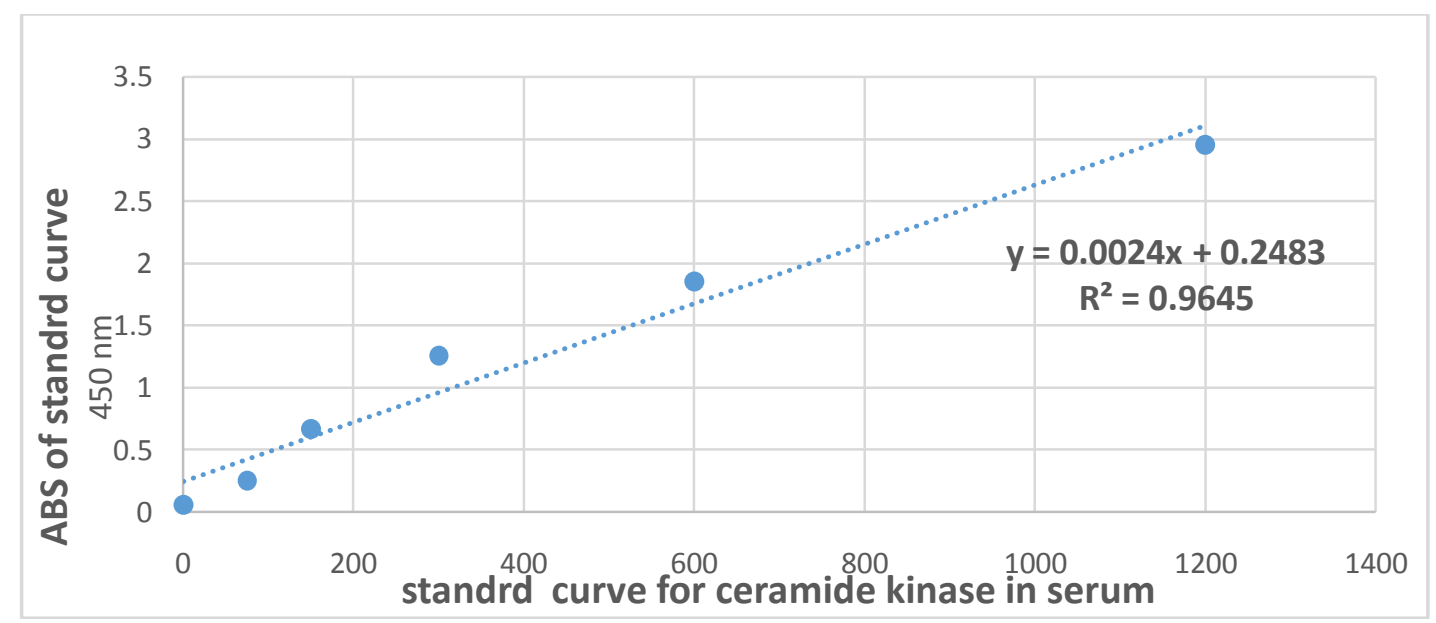

Figure 2:- standard curve of (CERK) concentration $(\mathrm{pg} / \mathrm{ml})$ in serum and tissue

\section{Discussion:-}

In Iraq, people with prostate cancer, according to statistics the Iraqi Ministry of Health is \% 5.06 in 2011, a very large number for that was the need to discuss ways and analyzes new reduce the incidence of this disease and it has been the use of advanced technology at a cost of good for early detection of prostate hyperplasia and malignant cancer and result was significant and detection for prostate cancer The concentration of S1P and Ceramide were different levels with control, and high levels in patients without any drugs or chemotherapy while levels of these markers still low with patients were taken drugs or chemotherapy and level of protein in tissue were raised. Results of biochemistry analysis still normal because we take patients without any D.M., renal failure, and hypertension. Approximately of the population in Western countries suffers from chronic pain syndrome there is a major need for renewed focus on novel targets that will be effective in both neuropathic and inflammatory pain. Compelling evidence implicates Ceramide-to-sphingosine 1-phosphate (S1P) pathways as contributors to pain of diverse etiologies. S1P and its receptors are emerging as important neuronal and immune cell regulators interacting at several sites in the pain pathway. Timely and important to critically evaluate the pharmacological basis for targeting the ceramide-to-S1P pathway as an approach to pain management (BraakM,et al, 2009). (P value) between control group and all groups were significant and (P value) between also two groups (BPH with and without drugs in serum and tissue) (PCa with high and low doses chemotherapy in serum and tissue) also founded significant. 


\section{Conclusion:-}

A significant inverse correlation between total S1P and Ceramide levels with BPH and Prostatic cancer.

The study concludes that increased incidence of Prostatic cancer with BMI and age.

Increase concentration of protein in tissue with BPH and PC and as well as being a marker that distinguishes indolent prostate cancer from those at risk of lethal progression.

\section{References:-}

1. Antoon, J.W.; White, M.D.; Burow, M.E.; Beckman, B.S. Dual inhibition of sphingosine kinase isoforms ablates TNF-induced drug resistance. Oncol. Rep. 2012; 27:1779-1786.

2. Abuhusain, H.J.; Matin, A.; Qiao, Q.; Shen, H.; Kain, N.; Day, B.W.; Stringer, B.W.; Daniels, B.; Laaksonen, M.A.; Teo, C.; et al. A metabolic shift favouring sphingosine 1-phosphate at the expense of ceramide controls glioblastoma angiogenesis. J. Biol. Chem. 2013; 288:37355-37364.

3. Anelli, V.; Gault, C.R.; Snider, A.J.; Obeid, L.M. Role of sphingosine kinase-1 in paracrine/transcellular angiogenesis and lymphangiogenesis in vitro. FASEB J. 2010; 24:2727-2738.

4. Antoon, J.W.; White, M.D.; Meacham, W.D.; Slaughter, E.M.; Muir, S.E.; Elliott, S.; Rhodes, L.V.; Ashe, H.B.; Wiese, T.E.; Smith, C.D.; et al. Antiestrogenic effects of the novel sphingosine kinase-2 inhibitor ABC294640. Endocrinology 2010; 151:5124-5135.

5. Arduengo, P.M. Sloppy technicians and the progress of science.wordpress.com/2010/03/15/sloppy-technicians Good, N.E. et al. (1966) Hydrogen ion buffers for biological research. Biochemistry. 2010 ; 5: 467-77.

6. Brizuela, L.; Ader, I.; Mazerolles, C.; Bocquet, M.; Malavaud, B.; Cuvillier, O. First evidence of sphingosine 1phosphate lyase protein expression and activity downregulation in human neoplasm: Implication for resistance to therapeutics in prostate cancer. Mol. Cancer Ther. 2012; 11: 1841-1851.

7. Bektas, M.; Allende, M.L.; Lee, B.G.; Chen, W.; Amar, M.J.; Remaley, A.T.; Saba, J.D.; Proia, R.L.Sphingosine 1-phosphate lyase deficiency disrupts lipid homeostasis in liver. J. Biol. Chem. 2010; 285: 10880-10889.

8. Baran, Y.; Salas, A.; Senkal, C.E.; Gunduz, U.; Bielawski, J.; Obeid, L.M.; Ogretmen, B.Alterations of ceramide/sphingosine 1-phosphate rheostat involved in the regulation of resistance to imatinib-induced apoptosis in K562 human chronic myeloid leukemia cells. J. Biol. Chem. 2007; 282:10922-10934.

9. Brügger, B.; Sachsenheimer, T.; Wieland, F.; et al. A critical role for ceramide synthase 2 in liver homeostasis: I. alterations in lipid metabolic pathways. J. Biol. Chem. 2010; 285:10902-10910. 